\title{
MULTIPLE MYELOMA WITH ADVANCED BONE DISEASE AND LOW TUMOR BURDEN - DIFFERENT CLINICAL PRESENTATION BUT SIMILAR OUTCOME AFTER BORTEZOMIB-BASED THERAPY AND RADIOTHERAPY
}

\author{
Vesselina Goranova-Marinova ${ }^{1}$, Marianna Yaneva ${ }^{2}$, Tanya Deneva ${ }^{3}$ and Stefan Goranov ${ }^{1}$ \\ ${ }^{1}$ Clinical Department of Hematology, ${ }^{2}$ Clinical Department of Radiotherapy and Nuclear Medicine, \\ ${ }^{3}$ Central Clinical Laboratory, Sv. Georgi University Hospital, Plovdiv Medical University, Plovdiv, Bulgaria
}

SUMMARY - There is a small but well recognized group of patients with multiple myeloma (MM), characterized by multiple bone lesions and low tumor burden, the so-called macrofocal form of MM (MF-MM). The aim of the study was to analyze the incidence, clinical manifestation, therapeutic outcome and prognosis of patients with MF-MM treated with bortezomib-based therapy and radiotherapy, in comparison to classic MM. There were $148 \mathrm{MM}$ patients treated with bortezomibbased regimens, with 15 (10.1\%) of them meeting the criteria for MF-MM. Comparative analysis involved disease- and therapy-related variables and markers of bone metabolism in MF-MM and classic MM groups. Event-free survival (EFS) and median survival (MS) were analyzed. Patients in MF-MM and classic MM groups had similar mean age and sex distribution. Patients with MF-MM had advanced myeloma bone disease (MBD), significantly lower clonal plasma cell infiltration in bone marrow, and lower paraprotein level. These patients were predominantly in an early International Staging System stage, showed non-secretory and light-chain variants, and significant association with extramedullary plasmacytomas. EFS was 20 months in MF-MM group versus 13 months in classic MM group (nonsignificant difference). MS was 42 months in both MF-MM and classic MM groups. MF-MM presents with imbalance of the minimal tumor burden and massive bone involvement. Along with advanced skeletal manifestations, these patients showed features of preserved bone marrow and no end-organ damages. Following bortezomib-based therapy and radiotherapy, the EFS and MS did not differ between MF-MM and classic MM groups.

Key words: Multiple myeloma; Bone and bones - pathology; Bortezomib - therapeutic use; Radiotherapy

\section{Introduction}

Generalized bone lesions affect clinical evolution of multiple myeloma (MM), create difficulties in defining the stage of the disease, its therapeutic outcome does not always follow the outcome of medullary dis-

Correspondence to: Vesselina Goranova-Marinova, MD, Clinical Department of Hematology, Sv. Georgi University Hospital and Plovdiv Medical University, 15A Vassil Aprilov Blv., 4002 Plovdiv, Bulgaria

E-mail: vesselina_goranova@yahoo.com

Received March 16, 2015, accepted April 3, 2017 ease, and myeloma bone disease (MBD) disables patients and deteriorates their prognosis. Usually, severe MBD reflects an advanced MM with high percentage of bone marrow plasma cell infiltration, high level of serum/urine paraprotein and end-organ damages.

A small proportion of MM patients present with multiple, generalized bone lesions and low tumor burden, i.e. low percentage of monoclonal plasma cells in bone marrow and low production of paraprotein or non-secretory variants. This group is called by some authors multifocal form of MM (MF-MM). The same term was used in our analysis. There are limited data in 
the literature on therapeutic options, outcome, monitoring of therapeutic response, prognostic factors and survival of these patients.

The aim of the study was to analyze the incidence, clinical manifestation, therapeutic outcome and prognosis of patients with MF-MM treated with bortezomib-based therapy and radiotherapy in comparison to classic MM.

\section{Patients and Methods}

During the period from January 2008 till June 2014, 148 patients with MM treated with bortezomib-based regimens were retrospectively studied. Their mean age was $60.16 \pm 9.43$ years and the male to female ratio was 1.05:1. The criteria for MF-MM were: MBD grade 2 and 3; clonal plasma cell infiltration in bone marrow less than 20\%; and paraprotein in serum $<25 \mathrm{~g} / \mathrm{L}$, paraprotein in urine $<1.0 \mathrm{~g} / 24 \mathrm{~h}$ by protein electrophoresis/immune fixation. Fifteen of 148 (10.1\%) patients fulfilled the criteria for MF-MM (Table 1). Clinical stage was defined according to the International Staging System (ISS). Bone lesions were assessed by conventional $\mathrm{x}$-ray of axial skeleton or computed tomography (CT) scan and magnetic resonance imaging (MRI) at the sites of interest. MBD was graded in four grades: 0 - no lytic bone lesions or osteoporosis; 1 - osteolytic lesions at $<3$ sites $+/$ - osteoporosis; $2-$ multiple bone lesions at $>3$ sites and/or pathologic fractures; and 3 - multiple lytic lesions and destructions of skeletal segments. All 148 patients were treated with bortezomib-based regimens in 21day cycles. Bortezomib (Millennium Pharmaceuticals, Inc., The Takeda Oncology Company, Cambridge, Massachusetts, USA) was administered in a dose of $1.3 \mathrm{mg} / \mathrm{m}^{2}$ on days $1,4,8$ and 11 , and was combined with dexamethasone (VelDex) in 31 (20.9\%), with cyclophosphamide (CyBorD) in 54 (36.5\%) and with anthracycline (PAD) in 14 (9.5\%) patients. Bortezomib regimen was administered as first line therapy in 53 (36.1\%), as second line therapy in $51(34.7 \%)$ and as $>$ second line therapy in $43(29.1 \%)$ patients. Five (33.33\%) patients underwent high-dose therapy with melphalan $200 \mathrm{mg} / \mathrm{m}^{2}$ with autologous stem-cell transplantation. Radiotherapy of lytic bone lesions, pathologic factures and soft tissue plasmacytomas was incorporated in therapeutic regimen when indicated. Patients underwent radiotherapy on a linear accelera-
Table 1. Clinical characteristics of $M F-M M$ patients in comparison to classic MM patients

\begin{tabular}{|l|l|l|l|}
\hline Parameter & $\begin{array}{l}\text { MF-MM } \\
\chi \pm \text { SEM }\end{array}$ & $\begin{array}{l}\text { Classic MM } \\
\chi \pm S E M\end{array}$ & p-value \\
\hline $\begin{array}{l}\text { Clonal plasma } \\
\text { cells in bone } \\
\text { marrow }\end{array}$ & $12.3 \pm 2.7$ & $63.12 \pm 8.33$ & $<0.001$ \\
$\begin{array}{l}\text { Paraprotein } \\
\text { in serum } \\
\text { Paraprotein } \\
\text { in 24-hour urine }\end{array}$ & $2.61 \pm 1.52$ & $43.37 \pm 2.42$ & $<0.001$ \\
\hline
\end{tabular}

$\mathrm{MM}=$ multiple myeloma; $\mathrm{MF}-\mathrm{MM}=$ macrofocal $\mathrm{MM}$

tor Siemens Mevatron Primus. Two main schemes of irradiation were used: $2 \times 8.5 \mathrm{~Gy}$ with an interval of 72 hours and $5 \times 4 \mathrm{~Gy}$. Three patients received irradiation at one of the affected sites with 1 fraction of $8 \mathrm{~Gy}$ as a single dose. Comparative analysis of the disease and therapy related variables and markers of bone metabolism (serum $\mathrm{Ca}$ and alkaline phosphatase, AP) was performed in patients with MF-MM and classic MM. As patients with MF-MM represent a unique problem in terms of therapeutic response because many of them lack a detectable monoclonal protein in serum and/or urine and myeloma cell infiltration in bone marrow is initially low, the event free survival (EFS) and median survival (MS) were assessed for analysis of outcome. Therapeutic response of MBD was assessed by the dynamics of bone pain, dynamics in the size of bone lesions and changes in the level of serum $\mathrm{Ca}$ and AP. Statistical analysis was performed by use of SPSS v. 18.0, using descriptive analysis, analysis of variation and analysis of alternatives, and independent samples T-test for independent samples. The method of Kaplan-Maier with log rank test was used for analysis of EFS and MS.

\section{Results}

Patients in the MF-MM and classic MM groups had similar mean age (60.6 \pm 7.32 vs. $60.11 \pm 9.67$ years) and similar sex distribution (Table 2).

\section{Clinical characteristics of MF-MM patients in comparison to classic MM}

By the principle of selection, in comparison with classic MM patients, all patients with MF-MM had 
Table 2. Patient characteristics in $M F-M M$ and classic MMgroups

\begin{tabular}{|l|l|l|l|}
\hline Parameter, n (\%) & MF-MM & Classic MM & p-value \\
\hline Sex: male & $9(60.0)$ & $64(48.1)$ & NS \\
female & $6(40.0)$ & $69(51.9)$ & \\
Renal failure & $1(6.7)$ & $49(37.1)$ & 0.013 \\
$\mathrm{Hb}<80 \mathrm{~g} / \mathrm{L}$ & 0 & $28(22.2)$ & 0.03 \\
Albumin $<30 \mathrm{~g} / \mathrm{L}$ & $1(6.7)$ & $43(34.1)$ & 0.012 \\
$\mathrm{LDH}>480 \mathrm{U} / \mathrm{L}$ & $4(26.7)$ & $29(23.0)$ & $\mathrm{NS}$ \\
Serum Ca & $4(26.7)$ & $22(17.5)$ & $\mathrm{NS}$ \\
$\mathrm{AP}<100 \mathrm{U} / \mathrm{L}$ & $3(20.0)$ & $34(32.4)$ & $\mathrm{NS}$ \\
$\beta 2 \mathrm{M}>3.5 \mathrm{mg} / \mathrm{L}$ & $1(6.7)$ & $50(40.0)$ & 0.012 \\
Extramedullary & $9(60.0)$ & $15(16.5)$ & $<0.001$ \\
plasmacytomas & & & \\
\hline
\end{tabular}

$\mathrm{MM}=$ multiple myeloma; $\mathrm{MF}-\mathrm{MM}=$ macrofocal $\mathrm{MM} ; \mathrm{Hb}=$ hemoglobin; $\mathrm{LDH}=$ lactate dehydrogenase; $\mathrm{AP}=$ alkaline phosphatase; $\beta 2 \mathrm{M}=$ beta $_{2}$-microglobulin; NS = nonsignificant

advanced $\mathrm{MBD}$, i.e. grade 2 and grade 3 was recorded in $5(100 \%)$ and $54(40.9 \%)$ patients, respectively $(\mathrm{p}<0.001) ;$ MF-MM patients also had significantly lower clonal plasma cell infiltration in bone marrow and lower level of paraprotein in serum and/or urine. These patients were predominantly in an early ISS stage and showed a significant predominance of nonsecretory and light-chain variants (Figs. 1 and 2). In the group of MF-MM, there were no patients with severe anemia, while the share of patients with renal failure, hypoalbuminemia and elevated beta $_{2}$-microglobulin $(\beta 2 \mathrm{M} ;>3.5 \mathrm{mg} / \mathrm{L})$ was significantly lower. MF-MM was significantly associated with extramedullary plasmacytomas (Table 2). The levels of hemoglobin and albumin were also significantly higher, while $\beta 2 \mathrm{M}$ and creatinine were significantly lower than in classic MM (Table 3). There was no betweengroup difference in the levels of $\mathrm{Ca}$ and $\mathrm{AP}$.

\section{Therapeutic outcome}

The mean number of bortezomib cycles was $6.07 \pm 1.06$ in MF-MM and 6.73 \pm 0.49 in classic MM group (NS). Patients with MF-MM were irradiated significantly more frequently than those with classic MM (14 (93.3\%) vs. 65 (49.9\%); p<0.001) and MFMM had a significantly higher mean number of irradiations $(2.53 \pm 0.34$ vs. $0.56 \pm 0.54 ; \mathrm{p}<0.001)$. Therapy alleviated bone pain in all patients, and in $9 / 15 \mathrm{pa}^{-}$

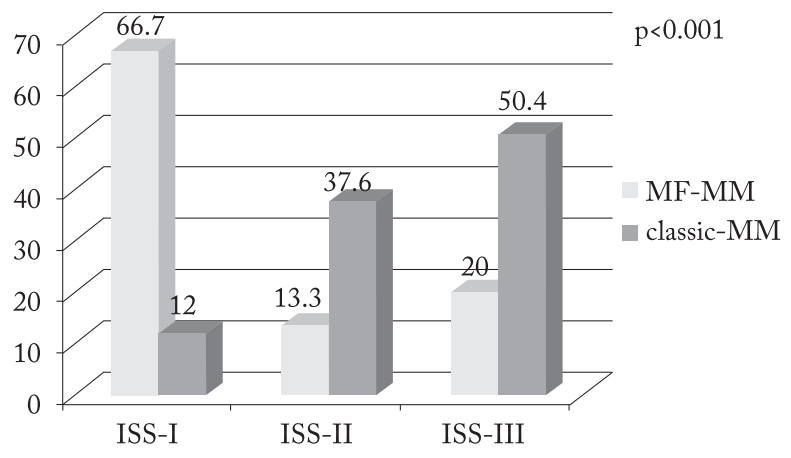

Fig. 1. Distribution according to the International Staging System (ISS) stage.

$\mathrm{MM}=$ multiple myeloma; $\mathrm{MF}-\mathrm{MM}=$ macrofocal $\mathrm{MM}$

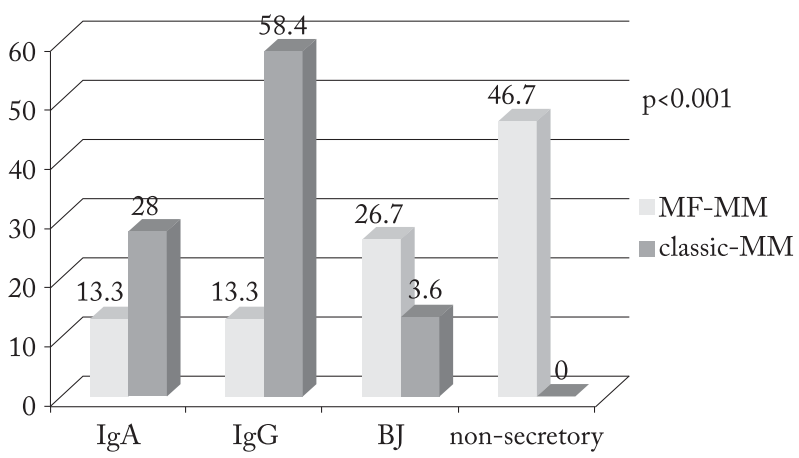

Fig. 2. Distribution according to immunologic variant.

$\mathrm{MM}=$ multiple myeloma; $\mathrm{MF}-\mathrm{MM}=$ macrofocal $\mathrm{MM}$

tients complete resolution of symptoms occurred. In 3 patients, reduction in the size of bone lesions was observed. Extramedullary formations were reduced in all patients, and in 11/15 patients they completely disappeared (fibrous tissue on enhanced CT scan). After therapy, a significant increase in the level of AP and decrease in the levels of $\mathrm{Ca}, \mathrm{LDH}$ and $\beta 2 \mathrm{M}$ was recorded (Table 4). There was a trend of longer EFS of 20 months (95\% confidence interval (95\% CI): 18.15221.848) in MF-MM group versus 13 months (95\% CI: 10.213-15.787) in classic MM group but the difference was not statistically significant (Fig. 3). MS was 42 months in both MF-MM and classic MM groups: MF-MM 95\% CI: 18.38-65.62 and classic MM 95\% CI: 37.04-46.96.

\section{Toxicity}

There was no significant difference in hematologic and non-hematologic toxicity between the two groups, 
Table 3. Mean values of some major parameters in patients with $M F-M M$ and classic $M M$

\begin{tabular}{|l|l|l|l|}
\hline Parameter & $\begin{array}{l}\text { MF-MM } \\
\chi \pm \text { SEM }\end{array}$ & $\begin{array}{l}\text { Classic MM } \\
\chi \pm S E M\end{array}$ & p-value \\
\hline $\mathrm{Hb}$ & $128.81 \pm 7.33$ & $96.5 \pm 1.7$ & $<0.001$ \\
Creatinine & $84.67 \pm 9.23$ & $167.17 \pm 15.19$ & $<0.001$ \\
LDH & $417.00 \pm 23.74$ & $395.29 \pm 14.47$ & $\mathrm{NS}$ \\
Albumin & $40.67 \pm 1.41$ & $34.15 \pm 0.63$ & 0.01 \\
B2M & $2.99 \pm 0.40$ & $7.13 \pm 0.57$ & $<0.001$ \\
Serum Ca & $2.58 \pm 0.12$ & $4.24 \pm 1.81$ & NS \\
AP & $165.67 \pm 18.15$ & $147.39 \pm 5.88$ & NS \\
\hline
\end{tabular}

$\mathrm{MM}=$ multiple myeloma; $\mathrm{MF}-\mathrm{MM}=$ macrofocal $\mathrm{MM} ; \mathrm{Hb}=$ hemoglobin; $\mathrm{LDH}=$ lactate dehydrogenase; $\beta 2 \mathrm{M}=$ beta $_{2}-$ microglob- $^{-}$ ulin; $\mathrm{AP}=$ alkaline phosphatase; $\mathrm{NS}=$ nonsignificant

Table 4. Dynamics of bone metabolism parameters and activity in patients with $M M$ and $M F-M M$ after therapy

\begin{tabular}{|l|l|l|l|}
\hline Parameter & $\begin{array}{l}\text { Before therapy } \\
\chi \pm S \chi\end{array}$ & $\begin{array}{l}\text { At best response } \\
\chi \pm S \chi\end{array}$ & $p$-value \\
\hline $\mathrm{AP}$ & $180.67 \pm 26.77$ & $207.07 \pm 24.45$ & 0.026 \\
$\mathrm{Ca}$ & $2.45 \pm 0.06$ & $2.31 \pm 0.04$ & 0.002 \\
$\mathrm{LDH}$ & $482.67 \pm 43.29$ & $410.33 \pm 34.29$ & 0.05 \\
$\beta 2 \mathrm{M}$ & $2.67 \pm 0.34$ & $1.67 \pm 0.12$ & 0.003 \\
\hline
\end{tabular}

$\mathrm{MM}=$ multiple myeloma; $\mathrm{MF}-\mathrm{MM}=$ macrofocal $\mathrm{MM} ; \mathrm{AP}=$ alkaline phosphatase; $\mathrm{LDH}=$ lactate dehydrogenase; $\beta 2 \mathrm{M}=$ beta $_{2}-\mathrm{mi}^{-}$ croglobulin

Table 5. Hematologic and non-hematologic toxicity

\begin{tabular}{|l|l|l|l|}
\hline Toxicity & MF-MM & Classic MM & p-value \\
\hline Polyneuropathy & $5(33.3)$ & $46(35.9)$ & NS \\
Thrombocytopenia & $1(6.7)$ & $25(19.2)$ & NS \\
Neutropenia & $2(13.4)$ & $11(8.5)$ & NS \\
Hypotension & $2(13.4)$ & $13(15.7)$ & NS \\
Gastrointestinal & $4(26.7)$ & $37(28.0)$ & NS \\
\hline
\end{tabular}

NS = nonsignificant

although patients with MF-MM had undergone more irradiation (Table 5). The most common side effect was peripheral polyneuropathy: 5 (33.3\%) versus 46 (35.9\%) in the MF-MM and classic MM group, respectively. There were no patients with polyeuropathy grade 3 and 4 .

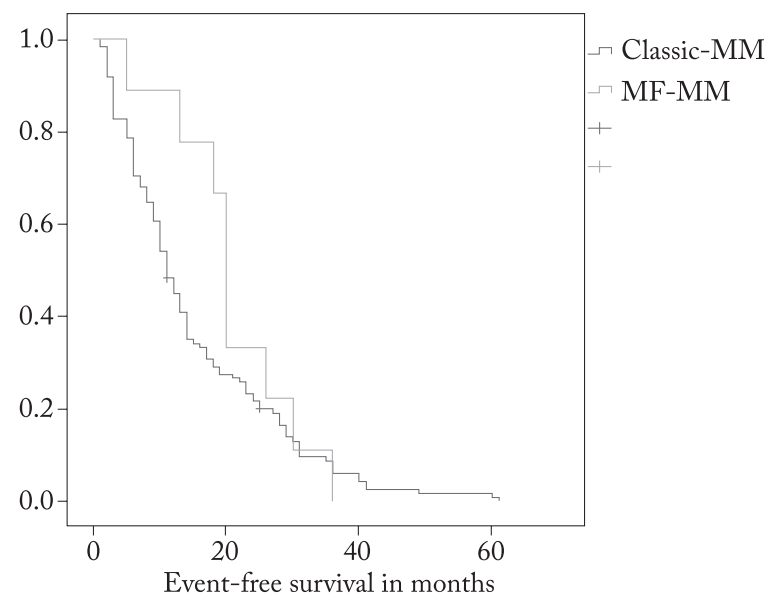

Fig. 3. Event-free survival in patients with $M F-M M$ and classic $M M$.

$\mathrm{MM}=$ multiple myeloma MF-MM = macrofocal $\mathrm{MM}$

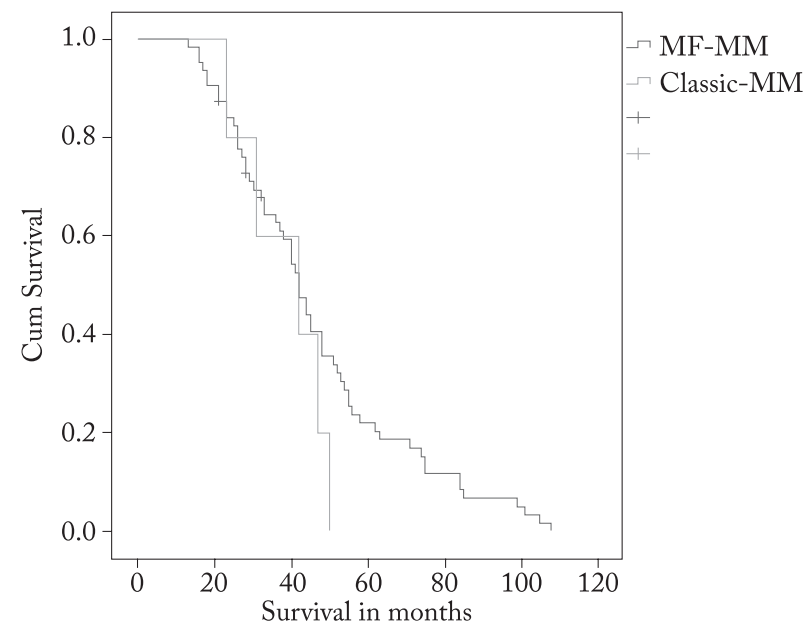

Fig. 4. Median survival in patients with $M F-M M$ and classic $M M$.

$\mathrm{MM}=$ multiple myeloma MF-MM = macrofocal $\mathrm{MM}$

\section{Discussion}

Intensive bone resorption is the earliest event in the evolution of $\mathrm{MM}^{1}$, while the increased number of osteoclasts $/ \mathrm{mm}^{2}$ pertrabecular bone surface is the most solid marker of monoclonal gammopathy of undetermined significance (MGUS) transformation into active $\mathrm{MM}^{2}$. Nowadays, the pathogenic mechanisms of bone resorption are a subject of profound research. Both the osteolytic lesions at the sites of plasma cell infiltration and distant humoral demineralization of 
bone are a result of the action of osteolytic cytokines secreted or induced by myeloma cells. A great number of osteolytic substances or 'osteoclast activating factors' have been discussed in the literature, e.g., tumor necrosis factor $\alpha$ (TNF- $\alpha)$, TNF- $\beta$, interleukin $1 \mathrm{~b}$ (IL-1b), IL-6, IL-10, IL-11, hepatocyte growth factor (HGF), matrix metalloproteinases (MMP) 2, 7, 9, and macrophage inflammatory protein (MIP- $1 \alpha$, MIP-1 $\beta)^{3}$. Nowadays, the critical role of the osteoprotegerin/receptor activator of NF-jB ligand (OPG/RANKL) system in bone remodeling in physiologic and pathologic conditions and in MM has been proven in many preclinical settings and in myeloma patients. The balance of the system is shifted towards RANKL overexpression and OPG suppression resulting in increased bone resorption and decreased bone formation. The role of Dickkopf protein-1 (DKK-1) as an inhibitor of osteoblast function is also important ${ }^{4-7}$. The negative quantitative balance of bone remodeling is a result of enhanced osteoclast function and suppressed osteoblast function reflected by the level of bone-specific AP. Until the era of novel agents, almost all drugs attacked the factors responsible for osteoclast activation, and no drug stimulated osteoblast function. With the introduction of bortezomib in clinical practice, it was proven that proteasome inhibition not only suppresses bone resorption but also affects positively osteoblast function ${ }^{8}$. There are data on a decrease of the markers of bone resorption and increase of the markers of bone synthesis in MM after treatment with bortezomib9 .

Patients with MF-MM present a specific feature, imbalance of the minimal tumor burden on the one hand, and massive bone involvement, i.e. multiple osteolytic lesions, fractures, and destructions of skeletal segments on the other hand. A parallel to light-chain (AL) amyloidosis is possible: in AL amyloidosis, low plasma cell tumor mass produces light chains with prominent tissue tropism; in MF-MM form, a higher expression of osteolytic cytokines with high bone impact is suspected. Although MF-MM form is rare, it poses significant difficulties in diagnosis, staging, prognostic assessment and therapy of patients. These patients share some common characteristics such as low tumor burden, i.e. low percentage of clonal plasma cells in bone marrow, and low production of serum and/or urine paraprotein, with a predominance of the non-secretory and light-chain variants. Minimal suppression of hematopoiesis and low $\mathrm{M}$-grade with rare immune paresis is reflected by the unusual normal levels of hemoglobin ${ }^{10}$, platelets and $\beta 2 \mathrm{M}$, and preserved renal function. The most prominent feature of MF$\mathrm{MM}$ is massive involvement of skeleton and frequent associations with soft tissue plasmacytomas ${ }^{11}$. There are contradictory data concerning the outcome of these patients. Smith et al. report that patients with non-secretory MM and multiple lytic bone lesions have a significantly shorter MS of 21 months versus 42 months ${ }^{12}$. In a retrospective study, Dimopoulous et al. found the incidence of MF-MM of 10/56 in young MM patients for a 20 -year period, therapeutic response rate of $55 \%$, and unreached MS. According to the authors, these patients had low tumor burden and better outcome with calculated MS of 8 years ${ }^{13}$. Kumar et al. describe atypical presentations of non-secretory $\mathrm{MM}$ and their frequent association with multiple bone lesions and plasmacytomas. They proved similar outcome and prognosis in these patients after autologous stem cell transplantation compared to the classic MM form ${ }^{11}$. Our patients shared the presenting features reported by most of the authors with identical MS in the two groups after therapy with bortezomibbased regimens and radiotherapy. The trend of longer PFS in our analysis may have been a reflection of the late diagnosis of relapse due to the absence or low grade $\mathrm{M}$-component. The dynamics of the bone metabolism markers of $\mathrm{Ca}$ and $\mathrm{AP}$ after therapy with bortezomib-based regimens plus radiotherapy reflected improved osteoblast and osteoclast function. While the rapid therapeutic response and improvement in the markers of MM activity are typical after bortezomib therapy, there are few data on the reduction in the size of ostelytic bone lesions and increase in the bone fraction of AP. Zangari et al. found a $25 \%$ increase of AP level above the baseline, which correlated with high $\mathrm{CR}+\mathrm{PR}$ rates and longer time to progression ${ }^{14}$. Heider $e t$ al. demonstrated significant elevation of osteocalcin and bone fraction of AP in parallel to reduction of collagen cross-links ${ }^{15}$. The mechanisms of improvement of bone lesions once they occur are still under investigation. Nowadays, the role of MRI and positron emission tomography-CT (PET-CT) in the assessment of MF-MM is proven as they differentiate plasma cell infiltration of bone marrow, osteolytic bone lesions and soft tissue plasmacytomas. These are the recommended methods for monitoring therapeutic response, with exceptional significance in non-secreto- 
ry MM, soft tissue plasmacytomas, as well as in the MF-MM group.

Myeloma tumor mass, transformed bone marrow microenvironment, multiple cell populations of osteoclasts, osteoblasts, osteocytes, stromal cells, endothelial cells, cell-to-cell interactions and humoral factors are being attacked with 'novel' agents. Hopefully, it is a matter of near future to disrupt the 'vicious circle' of $\mathrm{MM}$, i.e. as $\mathrm{MM}$ is more active, bone resorption is more intensive, and vice versa.

\section{References}

1. Valentin-Opran A, Charhon SA, Meunier PJ, Edouard CM, Arlot ME. Quantitative histology of myeloma-induced bone changes. Br J Haematol. 1982 Dec;52(4):601-10.

2. Bataille R, Chappard D, Marcelli C, Dessauw P, Baldet P, Sany $\mathrm{J}$, et al. Recruitment of new osteoblasts and osteoclasts is the earliest critical event in the pathogenesis of human multiple myeloma. J Clin Invest. 1991 Jul;88(1):62-6. DOI:10.1172/ JCI115305

3. Sezer O. Myeloma bone disease: recent advances in biology, diagnosis, and treatment. Oncologist. 2009 Mar;14(3):276-83. DOI:10.1634/theoncologist.2009-0003

4. Heider U, Zavrski I, Kühne CA, Heider U, Hofbauer LC, Zavrski I, Kaiser M, Jakob C, Sezer O. Novel aspects of osteoclast activation and osteoblast inhibition in myeloma bone disease. Biochem Biophys Res Commun. 2005 Dec 16;338(2):687-93. DOI:10.1016/j.bbrc.2005.09.146

5. Hofbauer LC. RANK ligand and osteoprotegerin in myeloma bone disease. Blood. 2003 Mar 15;101(6):2094-8.DOI:10.1182 /blood-2002-09-2684

6. Giuliani N, Rizzoli V, Roodman GD. Multiple myeloma bone disease pathophysiology of osteoblast inhibition. Blood. 2006 Dec 15;108(13):3992-6.DOI:10.1182/blood-2006-05-026112

7. Tian E, Zhan F, Walker R, Rasmussen E, Ma Y, Barlogie B, Shaughnessy JD Jr. The role of the Wnt-signaling antagonist
DKK1 in the development of osteolytic lesions in multiple myeloma. N Engl J Med. 2003 Dec 25;349(26):2483-94. DOI: 10.1056/NEJMoa030847

8. Terpos E, Sezer O, Croucher P, Dimopoulos MA. Myeloma bone disease and proteasome inhibition therapies. Blood. 2007 Aug 15;110(4):1098-104. DOI:10.1182/blood-2007-03$-067710$

9. Terpos E, Heath DJ, Rahemtulla A, Zervas K, Chantry A, Anagnostopoulos A, et al. Bortezomib reduces serum dickkopf-1 and receptor activator of nuclear factor-kappa B ligand concentrations and normalises indices of bone remodelling in patients with relapsed multiple myeloma. Br J Haematol. 2006 Dec; 135(5):688-92 DOI:10.1111/j.1365-2141.2006.06356.x

10. Županić-Krmek D, Lang N, Jurčić D, Ljubić N, Bilić A. Analysis of the influence of various factors on anemia in patients with lymphoid malignancies. Acta Clin Croat. 2011 Dec;50 (4):495-500.

11. Kumar S, Pérez WS, Zhang MJ, Ballen K, Bashey A, To LB, et al. Comparable outcomes in nonsecretory and secretory multiple myeloma after autologous stem cell transplantation. Biol Blood Marrow Transplant. 2008 Oct;14(10):1134-40. DOI: 10.1016/j.bbmt.2008.07.011

12. Smith DB, Harris M, Gowland E, Chang J, Scarffe JH. Non-secretory multiple myeloma: a report of 13 cases with a review of the literature. Hematol Oncol. 1986 Oct-Dec;4(4): 307-13.

13. Dimopoulos MA, Pouli A, Anagnostopoulos A, Repoussis P, Symeonidis A, Terpos E, et al. Macrofocal multiple myeloma in young patients: a distinct entity with favorable prognosis. Leuk Lymphoma. 2006 Aug;47(8):1553-6. DOI:10.1080/10428190 600647723

14. Zangari M, Esseltine D, Lee CK, Barlogie B, Elice F, Burns MJ, et al. Response to bortezomib is associated to osteoblastic activation in patients with multiple myeloma. Br J Haematol. 2005 Oct;131(1):71-3. DOI: 10.1111/j.1365-2141.2005.05733.x

15. Heider U, Kaiser M, Müller C, Jakob C, Zavrski I, Schulz CO, et al. Bortezomib increases osteoblast activity in myeloma patients irrespective of response to treatment. Eur J Haematol. 2006 Sep;77(3):233-8. DOI:10.1111/j.1600-0609.2006.00692.x 


\section{Sažetak \\ MULTIPLI MIJELOM S UZNAPREDOVALOM KOŠTANOM BOLEŠĆU I NISKIM TUMORSKIM OPTEREĆENJEM - RAZLIČITE KLINIČKE MANIFESTACIJE ALI SLIČAN ISHOD NAKON TERAPIJE NA OSNOVI BORTEZOMIBA I RADIOTERAPIJE}

\section{Goranova-Marinova, M. Yaneva, T. Deneva i S. Goranov}

Postoji manja, ali dobro prepoznata skupina bolesnika s multiplim mijelomom (MM) koja je obilježena višestrukim oštećenjima kostiju i niskim tumorskim opterećenjem, tzv. makrofokalni oblik MM (MF-MM). Cilj ovoga istraživanja bio je analizirati incidenciju, kliničke manifestacije, ishod terapije i prognozu u bolesnika s MF-MM liječenih terapijom na osnovi bortezomiba i radioterapijom u usporedbi s klasičnim MM. Ukupno je 148 bolesnika s MM liječeno terapijom na osnovi bortezomiba, od kojih je 15 (10,1\%) ispunjavalo kriterije za MF-MM. Usporedbena analiza obuhvatila je varijable povezane s bolešću i terapijom te biljege koštanog metabolizma u skupinama bolesnika s MF-MM i klasičnim MM. Analizirano je preživljenje bez ispada (event-free survival, EFS) te medijan preživljenja (median survival, MS). Distribucija prema srednjoj dobi i spolu bila je slična u skupinama s MF-MM i klasičnim MM. Bolesnici s MF-MM imali su uznapredovalu mijelomsku bolest kostiju, značajno niži stupanj infiltracije klonskih plazma stanica u koštanoj srži te nižu razinu paraproteina. Ovi bolesnici bili su pretežito u ranom stadiju prema Međunarodnom sustavu stadija bolesti, imali su ne-sekrecijske i lako-lančane varijante te značajnu pridruženost ekstramedularnih plazmacitoma. EFS je bio 20 mjeseci u skupini s MF-MM prema 13 mjeseci u skupini s klasičnim MM (neznačajna razlika). MS je bio 42 mjeseca u objema skupinama bolesnika. MF-MM se manifestirao kao neravnoteža minimalnog tumorskog opterećenja i velikim zahvaćanjem kostiju. Uz uznapredovale skeletne manifestacije, ovi bolesnici su imali očuvanu koštanu srž i izostanak oštećenja krajnjih organa. Nakon terapije zasnovane na bortezomibu i radioterapije nije bilo razlike u EFS i MS između skupina bolesnika s MF-MM i klasičnim MM.

Ključne riječi: Multipli mijelom; Kosti - patologija; Bortezomib - terapijska primjena; Radioterapija 